\title{
Empiema massivo em doente imunocompetente
}

\author{
Massive empyema in an imunocompetent patient
}

A espécie Citrobacter pode ser encontrada no meio ambiente, comumente no solo, água e alimentos, sendo também colonizantes do trato intestinal. ${ }^{1,2}$

Geralmente inofensivos, podem ser a fonte de infeção, estando os imunodeprimidos mais suscetíveis. ${ }^{2,3}$ Estes microrganismos adotam um papel mais relevante em infeções nosocomiais, por vezes com alta resistência a antibióticos, e atingindo doentes fragilizados e com várias comorbilidades. ${ }^{1,3,4}$

Descreve-se o caso de uma doente do género feminino, de 84 anos, com antecedentes de diabetes mellitus tipo 2, hipertensão arterial, e abcesso peri-hepático pós colecistectomia laparoscópica há 6 meses, com quadro de astenia com 3 semanas de evolução. Analiticamente apresentava elevação de parâmetros inflamatórios e a radiografia torácica mostrou derrame pleural direito. Foi internada no serviço de medicina interna por derrame pleural direito a esclarecer, com provável infeção subjacente, sob antibioterapia com Amoxicilina+Ácido Clavulânico. A tomografia computorizada torácica revelou derrame pleural septado, com empiema, de grande volume. Foi colocado dreno torácico, com drenagem de $1300 \mathrm{ml}$, contudo não se conseguiu drenar o restante volume. As hemoculturas foram negativas, porém o exame cultural do liquido pleural permitiu isolar Citrobacter braakii (Cb). Foi alterada antibioterapia para Piperaciclina/Tazobactam, de acordo com o teste de suscetibilidade antimicrobiana, porém com falência terapêutica. A doente foi submetida a cirurgia torácica de drenagem e descorticação pleural, com posterior melhoria clínica e radiológica progressiva.

As infeções por Cb são raras, com poucos casos descritos. ${ }^{5}$ Estudos demonstram uma prevalência de 3.8 a 9.5\% de Cb nas infeções causadas por Citrobacter spp., 1,2,4

Neste caso a presumível origem da infeção será uma contaminação ou translocação bacteriana na altura da cirurgia complicada por abcesso peri-hepático, sendo menos provável a possibilidade de infeção adquirida na comunidade, dada a raridade da mesma.

\section{Referências}

1 Nayar R, Shukla I, Sultan A. Epidemiology, Prevalence and Identification of Citrobacter Species in Clinical Specimens in a Tertiary Care Hospital in India. International Journal of Scientific and Research Publications. 2014; 4 (4): 1-6.

2 Samonis G, Karageorgopoulos DE, Kofteridis DP, Matthaiou DK, Sidiropoulou V, Maraki $S$ et al. Citrobacter infections in a general hospital: characteristics and outcomes. Eur J Clin Microbiol Infect Dis. 2009; 28:61-68.

3 Ariza-Prota MA, Pando-Sandoval A, García-Clemente M, Fernández R, Casan P. Community-Acquired Pneumonia and Empyema Caused by Citrobacter koseri in an Immunocompetent Patient. Case Rep Pulmonol. 2015; 2015:670373.

4 Mohan S, Agarwal J, Srivastava R, Singh M. Observations on Citrobacter species from a tertiary care health center with special reference to multi-drug resistance and presence of CTX-M gene. Indian J Pathol Microbiol. 2014; 57:439-41.

5 Hirai J, Uechi K, Hagihara M, Sakanashi D, Kinjo T, Haranaga S et al. Bacteremia due to Citrobacter braakii: A case report and literature Review. J Infect Chemother. 2016;1-3.
Fig 1. Derrame pleural septado, com empiema, de grande volume.

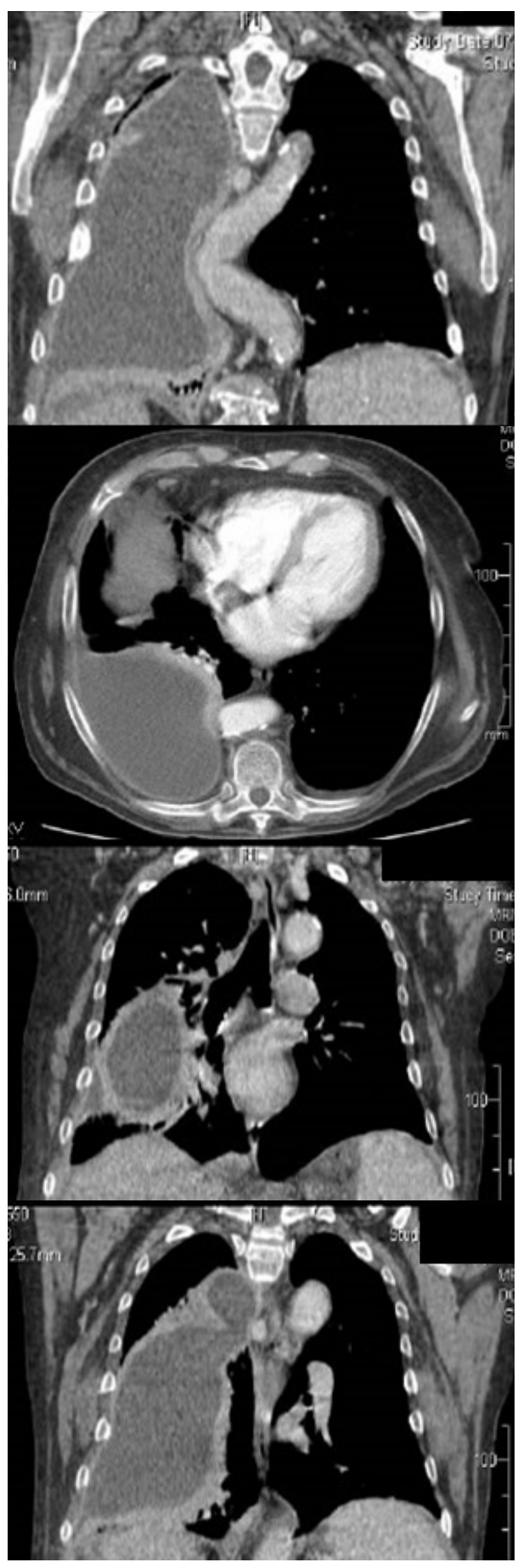

\section{Diagnóstico: Empiema massivo por Citrobacter braakii em doente imunocompetente}

Lilian Sousa, João Santos

Serviço de Medicina II, Centro Hospitalar de Leiria 